\title{
Applications of Cell Culture Studies in Pharmaceutical Technology
}

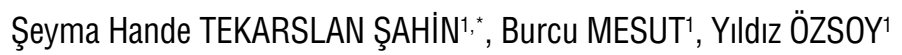 \\ 'Department of Pharmaceutical Technology, Faculty of Pharmacy, Istanbul University, Istanbul, Turkey
}

\begin{abstract}
There have been advances in the cell culture models for research and drug studies. The cytotoxicity and permeability of drug molecules and delivery systems are evaluated by cell culture models both in the pharmaceutical industry and in academia. Cell models serve as an important platform to investigate cytotoxicity and permeability studies by reducing the use of animal models. Since $3 \mathrm{D}$ cell models mimic in vivo cells better, it plays a significant role in the testing of drugs. This review article emphasizes an overview of cytotoxicity and permeability studies and $3 \mathrm{D}$ cell culture model used in pharmaceutical technology.
\end{abstract}

Key words: cell culture, cytotoxicity, permeability, pharmaceutical technology

\section{INTRODUCTION}

Studies conducted during the initial development of drugs such as toxicity, corrosion and drug activity were carried out on animals; however, in the past 10 to 20 years, alternatives have been sought due to the fact that animals do not effectively model human in vivo conditions and unexpected responses are observed in the studies. Cell culture studies made positive contributions to the initial development of drugs. Contrary to animal studies, the need for low drug and a short response time are the characteristics for in vitro cell culture methods ${ }^{1}$. In 2005, more than 100 million animals were used and 10 billion dollars were spent for animal toxicity experiments ${ }^{2}$. It is possible to reduce this cost and the amount of animal use for experiments with well-designed cell culture studies ${ }^{3}$.

Among other health authorities, the FDA, has recommended the use of the human cell line to identify metabolic pathways for drugs and shared their applicability in in vitro tests in guidelines published in 20044. In November 2013, the

\footnotetext{
*Corresponding author: hande.tekarslan@istanbul.edu.tr
} 
National Institutes of Health reported that more than 230 embryonic stem cell lines are appropriate for research ${ }^{5}$.

The number of publications on cytotoxicity and permeability studies using cell cultures as seen on PUBMED clearly shows that these topics have been trending higher over the past several years (Figure 1).

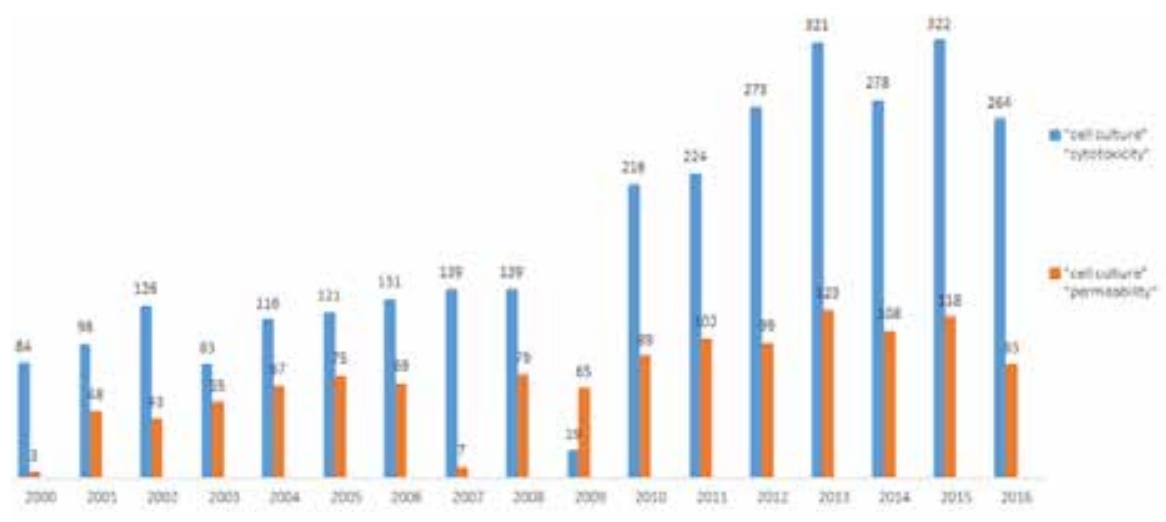

Publication Year

Figure 1. Numbers of publications in Pubmed using keywords 'cell culture', 'cytotoxicity' and 'permeability'.

\section{CANCER CELL LINES AS MODEL FOR DRUG STUDIES}

Cancer cell lines are used as a model for research and drug studies (Table 1). During the development of therapies, drugs are tested and developed by using cancer cell lines as an important model ${ }^{6}$. Drugs are tested on cancer cell lines by pharmaceutical companies ${ }^{7}$.

Table 1. Most used cancer cell lines (modified from Ferreira et al., 2013²).

\begin{tabular}{|l|l|l|}
\hline Cancer cell line & Species & Disease \\
\hline HeLa & Homo sapiens & Cervix adenocarcinoma \\
\hline Caco-2 & Homo sapiens & Colorectal adenocarcinoma \\
\hline MCF-7 & Homo sapiens & Breast adenocarcinoma \\
\hline A549 & Homo sapiens & Human lung carcinoma \\
\hline U87MG & Homo sapiens & Glioblastoma-astrocytoma \\
\hline HT-29 & Homo sapiens & Colon adenocarcinoma \\
\hline HEP-G2 & Homo sapiens & Hepatocellular carcinoma \\
\hline K-562 & Homo sapiens & Chronic myeloid leukaemia \\
\hline Cos7 & Cercopithecus aethiops & SV40 transformed - kidney \\
\hline PC3 & Homo sapiens & Prostate adenocarcinoma \\
\hline A375 & Homo sapiens & Malignant melanoma \\
\hline HEK 293 & Homo sapiens & Human Embryonic Kidney 293 cells \\
\hline CHO & Chinese hamster & Chinese hamster ovary cell line \\
\hline
\end{tabular}


The use of cancer cell lines for drug studies has advantages and disadvantages. Advantages of cancer cell lines are: They can be easily handled and manipulated. They have high homogeneity. Cancer cell lines have similarity with the initial tumour and it makes them advantageous to test cancer drugs on cancer cell lines. For experiments, they are unlimited auto-replication source and are easily substituted. The experiment results of the cancer cell lines for drug studies are reproducible. They also have disadvantages, such as they can be cross-contaminated with Hela cells. During studies, they can lose homogeneity and genomic stability, and they are also susceptible to contamination with bacteria and mycoplasma. And also, another difficulty is that the growth of long-term cancer cell lines is challenging.

\section{Drug Screening in Cancer Cell Lines}

Drug development begins with drug testing in cancer cell lines. Afterwards, drugs can be tried in in vivo clinical trials. Researchers have evaluated cytotoxicity of drugs on cancer cell lines for many years and data from these experiments have been proven to have clinical predictive value ${ }^{9,10}$. Diverse responses to drugs are displayed by different cancer cell lines ${ }^{9}$. Cell line panels are also useful for drug tests. The first cancer cell line is the panel NCI-60 which utilizes 60 cancer cell lines. This cancer cell line panel was developed to reduce animal experiments for testing of the drugs ${ }^{11}$. The mechanism, physiological processes and treatments of diseases can be explored by the help of the release of molecules from drug delivery carriers, drug diffusion tests and drug toxicity tests. Drug efficacy tests and drug toxicology tests are valuable as they present an alternative to animal experiments ${ }^{6,12}$. REACH is a regulation of European Union with four phases named registration, evaluation, authorization and restriction of chemicals and indicates that animal testing on chemicals should be avoided. 7 th Amendment to the Cosmetics Directive of European Union declares that finished cosmetic products and ingredients should be tested on alternative non-animal tests. This regulation of European Union has made cell-based experiments even more important ${ }^{13}$.

\section{In Vitro Systems for Toxicity Testing}

Cell culture conditions are improved to mimic more closely an in vivo growth environment. These improvements are co-culture with normal cells such as myofibroblasts and immune cells and three-dimensional (3D) matrices. Levels of specific growth factors and additives can be controlled by microfluidic perfusion systems $^{14}$.

Toxicity testing of new drugs will eventually be done in animal models to under- 
stand overall toxicity. If toxicity testing of new drugs is done in appropriate in vitro cell lines, limited animal model toxicity tests are needed. Toxicity tests on cell lines can be evaluated by testing the drug on a variety of cell types for which cell lines are available. These toxicity tests on cell lines can be an indication for the drug treatments for the cancer type which was studied ${ }^{14,15}$.

Although a suitable source of in vitro normal cell cultures were needed, only cancer cell lines were a suitable source for these tests. Normal cells from humaninduced pluripotent stem cells (hiPSC) and improved epithelial cell culture conditions can be used nowadays to broaden in vitro toxicity testing at the normal cellular level ${ }^{14,15}$. hiPSC-derived cardiomyocytes, endothelial cells, hepatocytes, and neuronal cells are commercially available. In the future, liver and heart cells will be available through these techniques to be tested and toxicity testing in whole animals may be reduced ${ }^{14}$.

\section{Cell Viability Assays}

Cell viability assays are widely used for in vitro drug and formulation toxicology studies. There are alternative assays for cell viability ${ }^{16,17,18}$. Commonly used assays are for cytotoxicity or cell viability detection: the MTT assay, the LDH assay, the neutral red, XTT assay and AlamarBlue assay. Activity of lactate dehydrogenase in the extracellular medium is measured by the LDH assay. Cell death is indicated by intracellular $\mathrm{LDH}$ release into the culture medium ${ }^{19}$. The neutral red assay also indicates cell viability. The neutral red is taken into the cell by living cells and sequestrated in the lysosomes of cells ${ }^{20,21}$. The MTT assay is a cell viability assay which determines cytotoxicity, and the validity of this assay was determined in cell lines ${ }^{22}$. MTT (3-(4,5-dimethylthiazol-2-yl)-2,5-diphenyltetrazolium bromide) is a tetrazolium salt. The tetrazolium ring of tetrazolium salt within the mitochondria is cleaved by succinate dehydrogenase, which results in its conversion to an insoluble purple formazan. The insoluble purple formazan accumulates in healthy cells due to the impermeability of the purple formazan to the cell membranes ${ }^{23}$. MTT or XTT are tetrazolium salt reduced to a colored formazan according to viable cell number ${ }^{16,17}$. Tetrazolium salts (MTT or XTT) are reduced by generation of $\mathrm{NADH}$ and NADPH. These colored formazans are measured in an automated colorimeter. MTT assay has an extra solubilization step for formazans which has to be dissolved in dimethylsulfoxide (DMSO) before colorimetric measurement. XTT tetrazolium assay was developed to eliminate this solubilization step and viable cells directly metabolize XTT reagent to a water soluble formazan ${ }^{16,24}$. Optical density in the culture wells can be directly read by calorimetry. Use of Alamar Blue as a fluorescent dye for cell viability tests started in $1993^{25}$. Alamar Blue is a non-fluorescent, non-toxic blue dye which is 
reduced to a pink fluorescent dye as a result of cell viability ${ }^{26}$.

Cell-based in vitro models have been used to study drug permeability through buccal (TR146 cell culture), intestinal (Caco-2 cell, TC7, MDCK, LLC-PK1), nasal (cultured nasal cells), pulmonary (Calu-3), ocular (corneal epithelial cells), rectal, vaginal (cervical cell lines) routes ${ }^{27}$. Among these, intestinal permeability is the most studied because the oral route of drug administriation is the most common $^{28}$.

\section{Intestinal Permeability by Cell Culture}

Genomics, proteomics, robotics and in silico chemistry are used to reduce costs in the drug discovery cycle. Understanding biopharmaceutical properties such as solubility, metabolic stability and intestinal permeability is an important task in the industry ${ }^{29}$. The physico-chemical properties of the active drug substance and its product, the physiological functions of body tissues and organs, and the complex process of drug absorption are influenced by physical and biochemical properties of the epithelial barrier ${ }^{30}$. While permeability of drug compounds through the intestinal membrane is a complex process ${ }^{29}$. The mechanism of drug transport in cell cultures is by passive transcellular and paracellular transport and active-carrier mediate transport ${ }^{31}$. The intestinal permeability of a drug can be evaluated by many techniques ${ }^{29}$. These methods are: 1) in vitro tissue methods (using diffusion chamber); 2) in vitro cell methods- (Caco-2; MDCK); 3) in vitro artificial membranes (parallel artificial membrane permeability assay (PAMPA) or immobilized artificial membrane (IAM) columns); 4) in vivo methods (whole animal pharmacokinetic studies; 5) in situ methods (single-pass perfusion); 6) computational approaches. These methods for the permeability assessment of drugs can be used individually or in combination. Cell culture models are preferred for the permeability assays due to predictability and throughput ${ }^{29}$. Recent studies for cell culture models for pharmaceutical technology are shown in Table 2.

Human cell culture models for the toxicity test of aerosolized nanoparticles are Alveolar epithelial cells (A549) and Airway epithelial cells (Calu-3, 16HBE140-, BEAS-2B $)^{32}$. As nanosized $\mathrm{ZnO}$ are used in sunscreens, the effect of the cytotoxicity of $\mathrm{ZnO}$ is important. Two commercially available $\mathrm{ZnO}$ powders' cytotoxicity was tested in human colon-derived RKO cells ${ }^{33}$. Albanese and Chan, 2011 produced transferin-coated gold particles by Frens method and they tested the effect of aggregation of particles on three different cell lines (HeLA, A549, MDAMD-435) due to the fact that aggregation of particles can affect toxicity. They concluded that uptake of particles are more affected than toxicity ${ }^{34}$. In another study, the effects of different sized silver nanoparticles on cytotoxicity were eval- 
Table 2. Examples of recent studies for pharmaceutical technology

\begin{tabular}{|c|c|}
\hline Studies & $\begin{array}{l}\text { Cell line used toxicity testing } \\
\text { /permeability test }\end{array}$ \\
\hline $\begin{array}{l}\text { In vitro cell exposure studies for the assessment of } \\
\text { nanoparticle toxicity in the lung-A dialog between aerosol } \\
\text { science and biology }\end{array}$ & $\begin{array}{l}\text { co-cultures of two different } \\
\text { epithelial cell lines, A549 and } \\
16 \mathrm{HBE} 140-\text { epithelia cell lines }\end{array}$ \\
\hline $\begin{array}{l}\text { Zn0 particulate matter requires cell contact for toxicity in } \\
\text { human colon cancer cells }{ }^{33}\end{array}$ & RKO colon cancer cells \\
\hline $\begin{array}{l}\text { Effect of gold nanoparticle aggregation on cell uptake } \\
\text { and toxicity }{ }^{34}\end{array}$ & HeLa and MDAMB-435 cells \\
\hline $\begin{array}{l}\text { Impact of silver nanoparticles on human cells: effect } \\
\text { of particle size }{ }^{35}\end{array}$ & $\begin{array}{l}\text { A549, SGC-7901, HepG2 and } \\
\text { MCF-7 cells }\end{array}$ \\
\hline $\begin{array}{l}\text { Cellular uptake and toxicity of gold nanoparticles in prostate } \\
\text { cancer cells: a comparative study of rods and spheres }\end{array}$ & PC-3 cells \\
\hline $\begin{array}{l}\text { Cytotoxicity and oxidative stress induced by different } \\
\text { metallic nanoparticles on human kidney cells }{ }^{37}\end{array}$ & $\begin{array}{l}\text { IP15 (glomerular mesangial) } \\
\text { and HK-2 (epithelial proximal) } \\
\text { cell lines }\end{array}$ \\
\hline $\begin{array}{l}\text { Thermoreversible Pluronic } ® \text { F127-based hydrogel } \\
\text { containing liposomes for the controlled delivery of } \\
\text { paclitaxel: in vitro drug release, cell cytotoxicity, and } \\
\text { uptake studies }{ }^{38}\end{array}$ & KB cancer cells \\
\hline $\begin{array}{l}\text { Cytotoxic effects of iron oxide nanoparticles and } \\
\text { implications for safety in cell labelling }\end{array}$ & $\begin{array}{l}\text { C17.2 neural progenitor cells, } \\
\text { PC12 rat pheochromocytoma } \\
\text { cells and human blood } \\
\text { outgrowth endothelial cells }\end{array}$ \\
\hline $\begin{array}{l}\text { Cytotoxicity induced by engineered silver nanocrystallites is } \\
\text { dependent on surface coatings and cell types }{ }^{40}\end{array}$ & $\begin{array}{l}\text { Mouse macrophage (RAW- } \\
264.7) \text { and lung epithelial } \\
(\mathrm{C}-10) \text { cell lines }\end{array}$ \\
\hline $\begin{array}{l}\text { Vitamin E TPGS coated liposomes enhanced cellular uptake } \\
\text { and cytotoxicity of docetaxel in brain cancer cells }\end{array}$ & C6 glioma cells \\
\hline $\begin{array}{l}\text { Curcumin loaded poly (2-hydroxyethyl methacrylate) } \\
\text { nanoparticles from gelled ionic liquid-In } \\
\text { vitro cytotoxicity and anti-cancer activity in SKOV-3 cells } \text { s }^{42}\end{array}$ & $\begin{array}{l}\text { SKOV-3 ovarian cancer cell } \\
\text { lines }\end{array}$ \\
\hline $\begin{array}{l}\text { Toxicity of copper oxide nanoparticles in lung epithelial } \\
\text { cells exposed at the air-liquid interface compared with in } \\
\text { vivo assessment. }{ }^{43}\end{array}$ & HBEC or A549 cells. \\
\hline $\begin{array}{l}\text { Cytotoxicity assessment of lipid-based self-emulsifying drug } \\
\text { delivery system with Caco-2 cell model: Cremophor EL as } \\
\text { the surfactant }{ }^{44}\end{array}$ & Caco-2 cells \\
\hline $\begin{array}{l}\text { Impact of lipid-based drug delivery systems on the transport } \\
\text { and uptake of insulin across Caco-2 cell monolayers }\end{array}$ & Caco-2 cells \\
\hline $\begin{array}{l}\text { Cellular uptake and transcytosis of lipid-based nanoparticles } \\
\text { across the intestinal barrier: relevance for oral drug } \\
\text { delivery }\end{array}$ & Caco-2 cells \\
\hline $\begin{array}{l}\text { Regional Morphology and Transport of PAMAM Dendrimers } \\
\text { Across Isolated Rat Intestinal Tissue } 47\end{array}$ & Caco-2 cells \\
\hline
\end{tabular}


uated on four human cell models (A549, SGC-7901, HepG2 and MCF-7). The experiments with $5 \mathrm{~nm}, 20 \mathrm{~nm}$ and $50 \mathrm{~nm}$ silver nanoparticles showed that the smallest - $(5 \mathrm{~nm})$ is the most toxic nanoparticle among them. They concluded that the reason may be that when nanoparticles are smaller, they enter cells more easily than larger ones ${ }^{35}$. Properties of gold nanoparticles make them an important tool for cancer therapy, gene delivery and cancer detection. Gold nanoparticles of various types (plain spherical, PEGylated spherical and PEGylated rods) were compared with each other to evaluate cytotoxicity on a human prostate cancer cell line (PC-3 cells). The results showed that the cytotoxicities of these gold nanoparticles were not different from one another ${ }^{36}$.

Metallic nanoparticles are used in medical treatments but can have a toxic effect on the kidneys. Pujalté et al., 2011 tested nanoparticles $\left(\mathrm{TiO}_{2}, \mathrm{ZnO}\right.$ and $\mathrm{CdS}$ ) which were produced for industry on human renal culture cells. While $\mathrm{TiO}_{2}$ nanoparticles showed no cytotoxicity, $\mathrm{ZnO}$ nanoparticles showed dose-dependent cytotoxicity and CdS nanoparticles are the most toxic ${ }^{37}$.

In another study, Paclitaxel loaded liposomes were incorporated into a thermoreversible hydrogel called Pluronic F127 in order to improve the solubility of paclitaxel and increase drug loading. Human oral cancer KB cell lines were incubated with PTX formulation loaded with liposomal 18\% F127 gel, Taxol or liposome. Blank liposomal F127 gel was found to be safer than pure liposome ${ }^{38}$.

Iron oxide nanoparticles are used for cell labelling in biomedical research. 4 different types of iron oxide nanoparticles were produced and their toxicity was tested on human blood outgrowth endothelial cells, C17.2 neural progenitor cells, and PC12 rat pheochromocytoma cells. Non-toxic concentration was determined for these nanoparticles to be used for the MR visualization ${ }^{39}$.

Silver nanoparticles were used for their antimicrobial properties and biomedical applications such as wound dressings. Different silver nanoparticles were produced. Toxicity measurements were performed on lung epithelial (C-10) cell lines and mouse macrophage (RAW-264.7). In this study, they concluded that surface charge and coating materials used in the synthesis, particle aggregation, and the cell-type used for the tests affect the cytotoxicity results. Based on cytotoxicity results, macrophage cells were found to be more sensitive than lung epithelial cells ${ }^{40}$.

In one study, liposomes coated with a PEGylated vitamin E (TPGS) with docetaxel were developed for treatment of brain tumours. Cytotoxicity of the liposomes were tested on C6 glioma cells. TPGS coated liposomes have higher cytotoxicity than PEG coated liposomes ${ }^{41}$. 
The anticancer activity of Curcumin loaded poly (2-hydroxyethyl methacrylate) nanoparticles was tested on ovarian cancer cells (SKOV-3) and the results showed that Curcumin loaded poly (2-hydroxyethyl methacrylate) nanoparticles exhibited a better level of tumor cells regression activity than free curcumin ${ }^{42}$.

In another study, an evaluation of the toxicity of copper oxide nanoparticles was performed on lung adenocarcinoma cells (A549 cells) and human bronchial epithelial cells (HBEC) using an in vitro air-liquid interface (ALI) exposure system. Exposure of CuONP significantly reduced cell viability in a dose-dependent manner. CuONP were more toxic on A549 cells than HBEC43.

Lipid-based self-emulsifying drug delivery systems are used for solubilizing poorly soluble drugs. When excipients and formulations are toxic, they damage cell monolayers and this artificially increases drug permeation. Understanding their toxicity is important for the correct interpretation of results. Bu et al., 2016 showed that using Cremophor EL as the surfactant did not damage the Caco2 cell layer and did not induce toxicity in the lipid-based self-emulsifying drug delivery system ${ }^{44}$.

In one study, Self-(nano)-emulsifying drug delivery systems (SNEDDSs) containing insulin were produced to transport insulin across the intestinal membrane. Size of SNEDDS were between 35-50 $\mathrm{nm}$. They demonstrated that two SNEDDS formulations increased the permability of insulin in Caco-2 cell monolayers ${ }^{45}$. In another study, permeability of nanostructured lipid carriers and solid lipid nanoparticles were compared and validated by Caco-2 cell monolayers. Permeability results of nanostructured lipid carriers were higher than solid lipid carriers ${ }^{46}$.

Intestinal permeability of Polyamidoamine (PAMAM) dendrimers were compared to Caco-2 monolayers and isolated rat intestinal regional mucosae. TEER values of Caco-2 monolayers and isolated rat intestinal regional mucosae matched each other ${ }^{47}$.

\section{Cell Culture Model for Drug Permeability Studies}

Absorption of drugs mostly occurs in the small intestinal region of the gastrointestinal tract. The small intestine selectively absorbs major nutrients, digests foreign substances and is a barrier to digestive enzymes. The surface of the small intestinal region increases the potential surface area available for digestion and absorption ${ }^{29}$. Models of human intestinal epithelium have been developed. This culture model is an ideal system to test the intestinal permeability of drug candidates. The Caco-2 cell is the model cell line which has been studied the most, characterized and is most useful for drug permeability studies ${ }^{48,49,50}$ (Figure 2). 


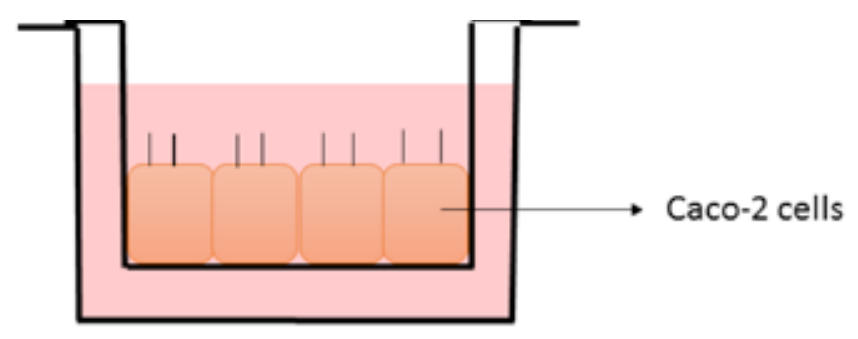

Figure 2. Caco-2 permeability assay.

Caco-2 is a human colon adenocarcinoma cell line ${ }^{48}$. It has well-established tight junctions and undergoes spontaneous enterocytic differentiation. Caco-2 is also used to predict the oral absorption of drugs in humans due to similarity of the Caco-2 cell line's permeation characteristics of drugs with permeation characteristics of human intestinal mucosa. Use of Caco-2 cells as a screening tool is becoming more widespread in the pharmaceutical industry. Lewis lung carcinoma-porcine kidney 1 (LLC-PK1) cells and Madin-Darby canine kidney (MDCK) are other cell line models used in permeability studies. Also, the 2/4/A1 line, transfected cells and Caco-2 cell clones are modified cell models which can be used for permeability studies. MDCK cell line is obtained from dog kidney cells. MDCK cell line is used as a model for intestinal permeability and use of this cell line as a model was first discussed in $1989^{51}$. Since then, MDCK cells were used for the permeability studies of early drug discovery compounds. Differentiation into columnar epithelial cells, formation of tight junctions and epithelial cell characteristics are common properties of Caco-2 and MDCK cells ${ }^{52}$. Permeation of passively absorbed drugs in Caco-2 cells and MDCK cells were correlated with each other.While Caco-2 cells grow in three weeks, MDCK cells grow in three days and it makes MDCK cells advantageous for the shorter cultivation period. As cell contamination and labour are disadvantage of longer cell culture time of Caco-2, shorter cultivation time of MDCK cells becomes important. The disadvantages of MDCK cells versus Caco-2 are: permeability values of drugs may be different for transporter-mediated uptake and/or efflux compounds due to species difference ${ }^{53}$. LLC-PK1 cells are also alternative cell line to Caco-2 for permeability studies and this porcine cell line can be utilized for the passive absorption of drugs ${ }^{54}$. The 2/4/A1 line is obtained from fetal rat intestine and passive paracellular permeability of 2/4/A1 line is similar to human small intestine. In vitro permeability models were improved by these modified cell lines for carrier mediated transport ${ }^{55,56}$.

\section{Challenges Associated with Cell Culture Models}

The use of cell culture models in permeability studies presents some issues; these are: Important transporters for drugs are expressed in Caco-2 cells ${ }^{57}$; however, expression of transporters in Caco-2 is lower than human small and large intes- 
tine ${ }^{58}$. Lower expression of these transporters may yield to less correlated results between Caco-2 cells and human intestine. Gene expression profiles of solute carrier transporters (SLC), efflux transporters (ABC) and cytochrome P-450 enzymes are different among Caco-2, MDCK and human intestine ${ }^{60}$. These differences may affect the permeability of compounds which are specific to transporters showing different expression profiles ${ }^{57}$. TEER values and permeability values of Caco-2 from different laboratories can be different due to varying culture conditions ${ }^{60,61,62}$. Although the transepithelial electrical resistance (TEER) of small intestine is estimated to be in the range of $25-40 \Omega \mathrm{cm}^{2}$, TEER of Caco-2 cells are $234 \Omega \mathrm{cm}^{2}$. Pore sizes of intestinal epithelium and Caco-2 cells are 5 $\AA$ and $6 \AA$, repectively ${ }^{63}$. When Caco-2 and MDCK cell lines were transfected with influx transporters, proper permeability results similar to human intestine were achieved. Cytochrome $\mathrm{P}_{450}\left(\mathrm{CYP}_{3} \mathrm{~A} 4\right)$ is oxidative CYP enzyme in intestine and it is less expressed in Caco-2 cells compared to human intestine ${ }^{64}$. Caco-2 cells can have different permeability values compared to human intestine due to cacophilicity, which means a drug reversibly binds to Caco-2 and it results in underestimation of permeability values. Although $\mathrm{pH}$ of human intestine varies from acidic to slightly basic $\mathrm{pH}^{65}$, Caco-2 grows in fixed $\mathrm{pH}$ conditions. After cellbased permeability studies, sample analysis is mostly done using LC-MS tools. However, high content of salt in the transport buffer affects LC-MS by interfering with ionization ${ }^{29}$.

\section{D CELL CULTURE MODELS}

Cell-based screening has been revolutionized by $3 \mathrm{D}$ cell culture technologies. While in $2 \mathrm{D}$ cell culture cells were grown on flat surfaces, in $3 \mathrm{D}$ cell culture cells were grown with the help of attachment surfaces such as extracted extracellular matrix (ECM ${ }^{66}$. The ECM is the complex mixture of proteins and sugars beyond the membrane of the cell ${ }^{67}$. Collagen, laminin and glycosaminoglycans, such as chondroitin sulfate and heparan sulfate are widely used components of ECM ${ }^{68,69}$. The basement membrane is a specialization of the ECM required for adhesion of the epithelial cell layer and responsible for a wide range of epithelial cell phenomena including cell identity, wound healing and migration ${ }^{69}$. ECM is not just a random mix of secreted components, but a specific composition of biochemicals and defined geometrical structure, which stimulates specific cell responses, such as differentiation ${ }^{70}$. Filter well inserts, sponges and gels and microcarriers are types of ECM. Filter well inserts are the first technology used for ECM ${ }^{66}$. 2D cell culture tests, animal model tests and clinical trials are the processes for drug discovery. Drugs may fail during phase III due to the toxicity of the drugs or efficacy of the drugs ${ }^{71,72}$. Drug test failures on $2 \mathrm{D}$ cell cultures led to the development of $3 \mathrm{D}$ cell cultures as an improved model for testing. Results of the drugs' responses 
are different between $2 \mathrm{D}$ and $3 \mathrm{D}$ cultures due to differences between $2 \mathrm{D}$ culture and human intestine. Understanding the toxicity of the new drug before animal tests is important in minimizing costs during research and development ${ }^{73,74}$. Cellular responses, spatial organization of cell surface receptors, gene expression and cellular behaviour in $3 \mathrm{D}$ culture cells can differ from $2 \mathrm{D}$ cell culture and it can be concluded that $3 \mathrm{D}$-cultured cells reflects in vivo cellular responses better than $2 \mathrm{D}$ cell culture ${ }^{75}$. $3 \mathrm{D}$ cell cultures are grown using a scaffold or in a scaffoldfree manner ${ }^{76}$. In $2 \mathrm{D}$ cell culture, cells form a monolayer while they are growing on a flat surface; attached cells proliferate. When they die, they detach from the surface and these dead cells are removed during the medium change ${ }^{77} .2 \mathrm{D}$ cells are flatter than in vivo cells. This dissimilar morphology affects the characteristics of the cells and they do not properly mimic the behaviours of the cells in the body. However, 2D cell culture is still the commonly used in vitro test in drug screening ${ }^{76}$.

In $3 \mathrm{D}$ cell culture, cell-cell interactions and cell-ECM interactions can provide the in vivo environment easily. $3 \mathrm{D}$ cell culture contains cells that are in various stages. Viable cells are at the outer part of the cluster, the core part contains cells at hypoxic state due to deficiency of medium ${ }^{78}$. The relative proliferation between $3 \mathrm{D}$ and 2D-cultured cells showed different trends and this proliferation rate difference also depends on cell line and matrix ${ }^{79,80,81,82} \cdot 3 \mathrm{D}$ cell culture has different gene, protein, and cell receptor expression compared to $2 \mathrm{D}$ cell culture $^{75}$. Susewind et al., 2016 developed a 3D intestinal model by embedding human macrophages (THP-1) and human dendritic cells (MUTZ-3) in a collagen cell and seeding Caco-2 cells on top of them. Non-inflamed and inflamed co-cultures were used to understand inflammation effects and cytotoxicity of nanoparticles. Comparison of Caco-2 monocultures and $3 \mathrm{D}$ co-cultures showed that cytotoxicity and interleukin release, which is an important biomarker for inflammation, was higher in $3 \mathrm{D}$ co-cultures ${ }^{83}$. Gomez-Roman et al., 2017 tested temozolomide, bevacizumab and erlotinib on 2D and $3 \mathrm{D}$ Glioblastoma cultures. They proved that these three drugs affect $2 \mathrm{D}$ and $3 \mathrm{D}$ cultures and $3 \mathrm{D}$ model responses were similar to clinical trials ${ }^{84}$. In a recent study by Ribas et al., 2016, the authors created a vascular microenvironment of the heart for drug development $^{85}$. In another recent study by Marsono et al., 2016, human iPSC-derived cardiomyocytes were used to stimulate $3 \mathrm{D}$ construction of myocardium ${ }^{86}$.

\section{CONCLUSION AND FUTURE PROSPECTS}

Cell culture is increasingly used in pharmaceutical research and regulators support the use of cell culture during the drug development stage. This review summarizes basic techniques of human cell line studies in the pharmaceutical tech- 
nology field. Cell-based experiments are highly predictive for preclinical drug toxicity and permeability assessments. It is assumed that, in the future, animal and human clinical trials will be greatly reduced by $3 \mathrm{D}$ cell culture experiments.

\section{AUTHOR CONTRIBUTIONS}

These authors contributed equally.

\section{REFERENCES}

1. Schleger, C.; Krebsfaenger, N.; Kalkuhl, A.; Bader, R.; Singer, T. (2001). Innovative cell culture methods in drug development. ALTEX 2001,18(1):5-8.

2. Taylor, K.; Gordon, N.; Langley, G.; Higgins, W. Estimates for Worldwide Laboratory Animal Use in 2005. ATLA 2008, 36:327-342.

3. Kura, A.U.; Fakurazi, S.; Hussein, M.Z.; Arulselvan, P. Nanotechnology in drug delivery: the need for more cell culture based studies in screening. Chem.Cent. J. 2014, 8:46. doi: $10.1186 / 1752-153 \mathrm{X}-8-46$.

4. http://www.fda.gov/downloads/ScienceResearch/SpecialTopics/CriticalPathInitiative/ CriticalPathOpportunitiesReports/UCM113411.pdf (last visit 15.04.2017).

5. Drug Discovery\&Development Website. (http://www.dddmag.com/article/2014/o1/newopportunities-stem-cells-drug-discovery-and-development). (last visit 15.04.2017)

6. Drewe, J.; Cai, S.X. Cell-based apoptosis assays in oncology drug discovery. Expert Opin Drug Discov 2010, 5(6):583-96. doi: 10.1517/17460441.2010.486829.

7. Gazdar, A.F.; Girard, L.; Lockwood, W.W.; Lam, W.L.; Minna, J.D.Lung cancer cell lines as tools for biomedical discovery and research. $J$ Natl Cancer Inst 2010, 102(17): 1310-1321.

8. Ferreira, D.; Adega, F.; Chaves, R. The Importance of Cancer Cell Lines as in vitro Models in Cancer Methylome Analysis and Anticancer Drugs Testing. In Oncogenomics and Cancer Proteomics - Novel Approaches in Biomarkers Discovery and Therapeutic Targets in Cancer, López-Camarillo, C.; Aréchaga-Ocampo, E., Eds.; Intech, 2o13; pp 139-166.

9. Finlay, G.J.; Baguley, B.C. The use of human cancer cell lines as a primary screening system for antineoplastic compounds. Eur J Cancer Clin On 1984, 20(7): 947-954.

10. Vargo-Gogola, T.; Rosen, J.M. Modelling breast cancer: one size does not fit all. Nat Rev Cancer 2007, 7(9): 659-672.

11. Shoemaker, R.H. The NCI6o human tumour cell line anticancer drug screen. Nat Rev Cancer 2006, 6(10):813-823.

12. Michelini, E.; Cevenini, L.; Mezzanotte, L.; Coppa, A.; Roda, A. Cell Based Assays: fuelling drug discovery. Anal Biochem 2010, 397:1-10.

13. Matsusaki, M.; Case, C.P.; Akashi, M. Three-dimensional cell culture technique and pathophysiology. Adv Drug Deliv Rev. 2014, 74:95-103.

14. Wilding, J.L.; Bodmer, W.F. Cancer Cell Lines for Drug Discovery and Development. Cancer Res 2014, 74(9):2377-2384.

15. Scott, C.W., Peters, M.F.; Dragan, Y.P. Human induced pluripotent stem cells and their use in drug discovery for toxicity testing. Toxicol Lett 2013 219:49-58. 
16. Scudiero, D.A.; Shoemaker, R.H.; Paull, K.D.; Monks, A.; Tierney, S.; Nofziger, T.H.; Currens, M.J.; Seniff, D.; Boyd, M.R. Evaluation of a soluble tetrazolium/formazan assay for cell growth and drug sensitivity in culture using human and other tumor cell lines. Cancer Res 1988, $48: 4827-4833$.

17. Alley, M.C.; Scudiero, D.A.; Monks, A.; Hursey, M.L.; Czerwinski, M.J.; Fine, D.L.; Abbott, B.J.; Mayo, J.G.; Shoemaker, R.H.; Boyd, MR. Feasibility of drug screening with panels of human tumor cell lines using a microculture tetrazolium assay. Cancer Res. 1988, 48:589-601.

18. Boyd, M.R.; Paull, K.D. Some practical considerations and applications of the National Cancer Institute in vitro anticancer drug discovery screen. Drug Dev Res 1995, 34:91-109.

19. Decker, T.; Lohmann-Matthes, M.L. A quick and simple method for the quantitation of lactate dehydrogenase release in measurements of cellular cytotoxicity and tumor necrosis factor (TNF) activity. J Immunol Methods 1988, 115(1): 61-69.

20. Fautz, R.; Husein, B.; Efstathiou, E.; Hechenberger-Freudl, C. Assessment of the relation between the initial viability and the attachment of freshly isolated rat hepatocytes used for the in vivo/in vitro DNA repair assay (UDS). Mutat Res 1993, 291(1):21-7.

21. Morgan, B.A.; Mittman, B.A.; Smith, M.M. The highly conserved N-terminal domains of histones $\mathrm{H}_{3}$ and $\mathrm{H}_{4}$ are required for normal cell cycle progression. Mol Cell Biol. 1991,11(8):4111-20.

22. Mosmann, T. Rapid colorimetric assay for cellular growth and survival: application to proliferation and cytotoxicity assays. J Immunol Methods. 1983, 65(1-2):55-63.

23. Berridge, M.V.; Herst, P.M.; Tan, A.S. Tetrazolium dyes as tools in cell biology: new insights into their cellular reduction. Biotechnol Annu Rev 2005, 11:127-52.

24. Paull, K.D.; Shoemaker, R.H.; Boyd, M.R.; Parsons, J.L.; Risbood, P.A.; Barbera, W.A.; Sharma, M.N.; Baker, D.C.; Hand, E.; Scudiero, D.A.; Monks, A.; Alley, M.C.; Grote, M.The synthesis of XTT: A new tetrazolium reagent that is bioreducible to a water-soluble formazan. $J$ Heterocyclic Chem 1988,25:911-914.

25. Fields, R.D.; Lancaster, M.V. Dual-attribute continuous monitoring of cell proliferation/ cytotoxicity. Am Biotechnol Lab. 1993, 11(4):48-50.

26. Slater, K. Cytotoxicity tests for high-throughput drug discovery. Curr Opin Biotechnol 2oo1, 12(1):70-4.

27. Sarmento, B.; Andrade, F.; da Silva, S.B.; Rodrigues, F.; das Neves, J.; Ferreira, D.Cellbased in vitro models for predicting drug permeability. Expert Opin Drug Metab Toxicol 2012, 8(5): 607-621

28. Wang, J.; Skolnik, S. Permeability diagnosis model in drug discovery: a diagnostic tool to identify the most influencing properties for gastrointestinal permeability. Curr Top Med Chem. 2013,13(11): 1308-1316.

29. Balimane, P.V.; Chong, S.Cell culture-based models for intestinal permeability: a critique. Drug Discov Today 2005, 10(5):335-43.

30. Volpe, D.A. Application of Method Suitability for Drug Permeability Classification. AAPS J 2010, 12(4):670-8.

31. Kell, D.B.; Dobson, P.D.; Oliver, S.G.Pharmaceutical drug transport: the issues and the implications that it is essentially carrier-mediated only. Drug Discov Today. 2011, (15-16):704-14

32. Paur, H.R.;Cassee, F.R.; Teeguarden, J.; Fissan, H.; Diabate, S.; Aufderheide, M.; Krey- 
ling, W.G.; Hanninen, O.; Kasper, G.; Riediker, M.; Rothen-Rutishauser, B.; Schmid, O. Invitro cell exposure studies for the assessment of nanoparticle toxicity in the lung-A dialog between aerosol science and biology. $J$ Aerosol Sci 2011, 42: 668-692.

33. Moos, P.J., Chung, K.; Woessner, D.; Honeggar, M.; Cutler, N.S.; Veranth, J.M. ZnO particulate matter requires cell contact for toxicity in human colon cancer cells. Chem Res Toxicol 2010, 19;23(4):733-9. doi: 10.1021/tx900203v.

34. Albanese, A.; Chan, W.C.W. Effect of gold nanoparticle aggregation on cell uptake and toxicity. ACS Nano 2011, 5(7):5478-89.

35. Liu, W.; Wu, Y.; Wang, C.; Li, H.C.; Wang, T.; Liao, C.Y.; Cui, L.; Zhou, Q.F.; Yan, B.; Jiang, G.B.Impact of silver nanoparticles on human cells: effect of particle size. Nanotoxicology $\mathbf{2 0 1 0}$, 4(3):319-30.

36. Malugin, A.; Ghandehari, H. Cellular uptake and toxicity of gold nanoparticles in prostate cancer cells: a comparative study of rods and spheres. J Appl Toxicol 2010, 30(3):212-7.

37. Pujalté, I.; Passagne, I.; Brouillaud, B.; Tréguer, M.; Durand, E.; Ohayon-Courtès, C.; L'Azou, B.Cytotoxicity and oxidative stress induced by different metallic nanoparticles on human kidney cells. Part Fibre Toxicol 2011, 8:10, doi: 10.1186/1743-8977-8-10.

38. Nie, S.; Hsiao, W.L.; Pan, W.; Yang, Z. Thermoreversible Pluronic F127-based hydrogel containing liposomes for the controlled delivery of paclitaxel: in vitro drug release, cell cytotoxicity, and uptake studies. Int $J$ Nanomedicine. 2o11, 6:151-66.

39. Soenen, S.J.; Himmelreich, U.; Nuytten, N.; De Cuyper, M. Cytotoxic effects of iron oxide nanoparticles and implications for safety in cell labelling. Biomaterials 2011, 32(1):195-205.

40. Suresh, A.K.; Pelletier, D.A.; Wang, W.; Morrell-Falvey, J.L.; Gu, B.; Doktycz, M.J.Cytotoxicity induced by engineered silver nanocrystallites is dependent on surface coatings and cell types. Langmuir 2012, 28(5):2727-35.

41. Muthu, M.S.; Kulkarni, S.A.; Xiong, J.; Feng, S.S. Vitamin E TPGS coated liposomes enhanced cellular uptake and cytotoxicity of docetaxel in brain cancer cells. Int $J$ Pharm. 2011, 421(2):332-40.

42. Kumar, S.S.; Surianarayanan, M.; Vijayaraghavan, R.; Mandal, A.B.; MacFarlane, D.R.Curcumin loaded poly (2-hydroxyethyl methacrylate) nanoparticles from gelled ionic liquid-In vitro cytotoxicity and anti-cancer activity in SKOV-3 cells. Eur J Pharm Sci. 2014, 51:34-44.

43. Jing, X., Park, J.H.; Peters, T.M.; Thorne, P.S. Toxicity of copper oxide nanoparticles in lung epithelial cells exposed at the air-liquid interface compared with in vivo assessment. Toxicol In Vitro. 2015, 29(3): 502-511.

44. Bu, P.; Narayanan, S.; Dalrymple, D.; Cheng, X.; Serajuddin, A.T.Cytotoxicity assessment of lipid-based self-emulsifying drug delivery system with Caco-2 cell model: Cremophor EL as the surfactant. Eur J Pharm Sci 2016, 91:162-71.

45. Li, P; Nielsen, H.M.; Müllertz, A. Impact of lipid-based drug delivery systems on the transport and uptake of insulin across Caco-2 cell monolayers. $J$ Pharmha Sci 2016,105(9):2743-51.

46. Neves, A.R.; Queiroz, J.F.; Costa Lima, S.A.; Figueiredo, F.; Fernandes, R.; Reis, S. Cellular uptake and transcytosis of lipid-based nanoparticles across the intestinal barrier: relevance for oral drug delivery. $J$ Colloid Interface Sci 2016, 463:258-65.

47. Hubbard, D.; Bond, T.; Ghandehari, H. Regional Morphology and Transport of PAMAM 
Dendrimers Across Isolated Rat Intestinal Tissue. Macromol Biosci. 2015, 15(12):1735-43.

48. Artursson, P. Cell cultures as models for drug absorption across the intestinal mucosa. Crit. Rev. Ther. Drug Carrier Syst 1991, 8: 305-330.

49. Artursson, P.; Karlsson, J. Correlation between oral drug absorption in humans and apparent drug permeability coefficients in human intestinal epithelia (Caco-2) cells. Biochem. Biophys. Res. Commun. 1991, 175: 880-890.

50. Rubas, W., Cromwell, M.E., Shahrokh, Z.; Villagran, J.; Nguyen, T.N.; Wellton, M.; Nguyen, T.H.; Mrsny, R.J.Flux measurements across Caco-2 monolayers may predict transport in human large intestinal tissue. J Pharm Sci 1996, 85: 165-169.

51. Cho, M.; Thompson, D.P.; Cramer, C.T.; Vidmar, T.J.; Scieszka, J.F. The MDCK epithelial cell monolayer as a model cellular transport barrier. Pharm Res 1989, 6: 71-77.

52. Irvine, J., Takahashi, L.; Lockhart, K.; Cheong, J.; Tolan, J.W.; Selick, H.E.; Grove, J.R. MDCK cells: a tool for membrane permeability screening. J. Pharm. Sci. 1999, 88, $28-33$.

53. Putnam, W.; Ramanathan, S.; Pan, L.; Takahashi, L.H.; Benet, L.Z. Functional characterization of monocarboxylic acid, large neutral amino acid, bile acid and peptide transporters, and P-gp in MDCK and Caco-2 cells. J. Pharm. Sci. 2002, 91: 2622-2635.

54. Li, H.; Chung, S.J.; Shim, C.K. Characterization of the transport of uracil across Caco-2 and LLC-PK1 cell monolayers. Pharm Res 2002, 19(10):1495-501.

55. Han, H.; de Vrueh, R.L.; Rhie, J.K.; Covitz, K.M.; Smith, P.L.; Lee, C.P.; Oh, D.M.; Sadée, W.; Amidon, G.L. 5'-Amino acid esters of antiviral nucleosides, acyclovir, and AZT are absorbed by the intestinal PEPT1 peptide transporter. Pharm Res. 1998, 15(8):1154-9.

56. Tang, F.; Horie, K.; Borchardt, R.T.Are MDCK cells transfected with the human MDR1 gene a good model of the human intestinal mucosa? Pharm. Res 2002,19:765-772.

57. Sun, D.; Lennernas, H;, Welage, L.S.; Barnett, J.L.; Landowski, C.P.; Foster, D.; Fleisher, D.; Lee, K.D.; Amidon, G.L.Comparison of human duodenum and Caco-2 gene expression profiles for 12,000 gene sequences tags and correlation with permeability of 26 drugs. Pharm Res 2002, 19(10):1400-16.

58. .Anderle, P.; Huang, Y.; Sadée, W. Intestinal membrane transport of drugs and nutrients: genomics of membrane transporters using expression microarrays. Eur J Pharm Sci. 2004, 21(1):17-24.

59. Quan, Y.; Jin, Y.; Faria, T.N.; Tilford, C.A.; He, A.; Wall, D.A.; Smith, R.L.; Vig, B.S. Expression Profile of Drug and Nutrient Absorption Related Genes in Madin-Darby Canine Kidney (MDCK) Cells Grown under Differentiation Conditions. Pharmaceutics. 2012, 4(2):314-33.

60. Walter, E.; Kissel, T. Heterogeneity in the human intestinal cell line Caco-2 leads to differences in transepithelial transport. Eur J Pharm Sci 1995,3: 215-230.

61. Hidalgo, I. Assessing the absorption of new pharmaceuticals. Curr Top Med Chem 2oo1, $1,385-401$.

62. Ingels, F.; Augustijns, P.Biological, pharmaceutical, and analytical considerations with respect to the transport media used in the absorption screening system, Caco-2. J. Pharm. Sci. 2003, 92,1545-1558.

63. Linnankoski, J.; Mäkelä, J.; Palmgren, J.; Mauriala, T.; Vedin, C.; Ungell, A.L.; Lazorova, L.; Artursson, P.; Urtti, A.; Yliperttula, M. Paracellular porosity and pore size of the human 
intestinal epithelium in tissue and cell culture models. J Pharm Sci. 2011, 99(4):2166-75

64. Benet, L.Z.; Cummins, C.L.; Wu, C.Y.Transporter-enzyme interactions: implications for predicting drug-drug interactions from in vitro data. Curr Drug Metab 2003, 4(5):393-8.

65. Dressman, J.B.; Bass, P.; Ritschel, W.A.; Friend, D.R.; Rubinstein, A.; Ziv, E.Gastrointestinal parameters that influence oral medications. J Pharm Sci. 1993, 82(9):857-72.

66. Justice, B.A.; Badr, N.A.; Felder, R.A. 3D cell culture opens new dimensions in cell-based assays. Drug Discov Today. 2009, 14(1-2):102-7

67. Griffith, L.G.; Swartz, M.A.Capturing complex 3D tissue physiology in vitro. Nat. Rev. Mol. Cell Biol. 2006, 7,:211-224.

68. Miner, J.H. Laminins and their roles in mammals. Microsc. Res. Tech. 2oo8, 71, 349-356.

69. Simons, M.; Mlodzik, M. Planar cell polarity signaling: From fly development to human disease. Annu Rev Genet 2008, 42:517-40.

70. Adams, C.A.;Watt, F.M. Regulation and development of differentiation by the extracellular matrix. Development 1993, 117:1183-1198.

71. DiMasi, J.A.; Grabowski, H.G.Economics of new oncology drug development. J Clin Oncol 2017, 25:209-216.

72. Breslin, S.; O’Driscoll, L.Three-dimensional cell culture: the missing link in drug discovery. Drug Discov Today 2013, 18:240-249.

73. Hopkins, A.L.Network pharmacology: the next paradigm in drug discovery. Nat Chem Biol 2008, 4:682-690.

74. Kola, I. The state of innovation in drug development. Clin Pharmacol Ther 2oo8, 83:227230.

75. Lee, J.; Cuddihy, M.J.; Kotov, N.A. Three-dimensional cell culture matrices: state of the art. Tissue Eng Part B Rev 2008, 14:61-86.

76. Edmondson, R.; Broglie, J. J.; Adcock,A.F.;Yang, L. Three-Dimensional Cell Culture Systems and Their Applications in Drug Discovery and Cell-Based Biosensors.Assay Drug Dev Technol 2014, 12(4): 207-218. doi:10.1089/adt.2014.573.

77. Huang, H.; Ding, Y.; Sun, X.S.; Nguyen, T.A. Peptide hydrogelation and cell encapsulation for $3 \mathrm{D}$ culture of MCF-7 breast cancer cells. PLoS One 2013,8:e59482.

78. Mehta, G.; Hsiao, A.Y.; Ingram, M.; Luker, G.D.; Takayama, S. Opportunities and challenges for use of tumor spheroids as models to test drug delivery and efficacy. $J$ Control Release $\mathbf{2 0 1 2}$, 164:192-204.

79. Gurski, L.; Petrelli, N.; Jia, X.; Farach-Carson, M. Three-dimensional matrices for anti-cancer drug testing and development. Oncol Issues 2010, 25:20-25.

80. Chitcholtan, K.; Sykes, P.; Evans, J.The resistance of intracellular mediators to doxorubicin and cisplatin are distinct in $3 \mathrm{D}$ and 2D endometrial cancer. $J$ Transl Med 2012, 10:1-16.

81. Fallica, B.; Maffei, J.S.; Villa, S.; Makin, G.; Zaman, M. Alteration of cellular behavior and response to PI3K pathway inhibition by culture in $3 \mathrm{D}$ collagen gels. PloS One 2012, 7:e48024.

82. Luca, A.C.; Mersch, S.; Deenen, R.; Schmidt, S.; Messner, I.; Schäfer, K.L.; Baldus, S.E.; Huckenbeck, W.; Piekorz, R.P.; Knoefel, W.T.; Krieg, A.;Stoecklein, N.H. Impact of the 3D microenvironment on phenotype, gene expression, and EGFR inhibition of colorectal cancer 
cell lines. PLOS ONE 2013,8:e59689.

83. Susewind, J.; de Souza Carvalho-Wodarz, C.; Repnik U.; Collnot, E.M.; Schneider-Daum, N.; Griffiths, G.W.; Lehr, C.M. A 3D co-culture of three human cell lines to model the inflamed intestinal mucosa for safety testing of nanomaterials. Nanotoxicology 2016, 10(1):53-62.

84. Gomez-Roman, N.; Stevenson, K.; Gilmour, L.; Hamilton, G.; Chalmers, A.J. A novel 3D human glioblastoma cell culture system for modeling drug and radiation responses. Neuro Oncol 2017, 19(2):229-241.

85. Ribas, J.; Sadeghi, H.; Manbachi, A.; Leijten, J.; Brinegar, K.; Zhang, Y. S.; Ferreira, L.; Khademhosseini, A. Appl In Vitro Toxicol 2016, 2(2):82-96.

86. Marsano, A.; Conficconi, C.; Lemme, M., Occhetta, P.; Gaudiello, E.; Votta, E.; Cerino, G.; Redaelli, A.; Rasponi, M. Beating heart on a chip: a novel microfluidic platform to generate functional 3D cardiac microtissues. Lab Chip 2016, 16(3):599-610.

(Received 18 April 2017; accepted 25 May 2017) 